The Japanese Journal of Experimental

Social Psychology. 1985, Vol. 24, No. 2, 135-141

〔原 著]

\title{
社会的相互作用過程における期待が 対人知覚の変容飞及ほす効果
}

\author{
九州大学 \\ 崔 光 善
}

\begin{abstract}
問
題

本研究は, 他者 (期待者) と自己（被期待者）の相互 作用において，他者の期待によって起てった自己行動の 変容を知覚した被期待者は, それまでの白己概念および 他者についての知覚をどのように変容させるかを解明す るととによって，期待が対人知覚の変容に及ぼす影響を 明らかにしようとするものである。
\end{abstract}

Darley \& Fazio (1980) は, 期待者と被期待者間の社 会的相互作用の 1 つのモデルとして，6段階の期待確認 過程を提示している。それらは，(a)期待者の被期待者 に対する期待の形成，(b)期待に一致する期待者の行動, （c）期待者の行動についての被期待者の解釈，(d)被期 待者の反応, (e) 被期待者の反応についての期待者の解 釈，(f)被期待者の自分自身の反応についての解釉であ る。期待者の期待と被期待者の行動の変容に関わる段階 は，(a)〜 (e)であると考えられる。すなわち，てれは 期待者の被期待者に対する弁別的行動を被期待者が認知 するととによって，被期待者のパフォーマンスが影帮を 受けるプロセスである。

今までの期待に関する殆んどの研究は上記 $(\mathrm{a}) \sim(\mathrm{e})$ の段階までの研究が多い, 期待は果たして期待された行 動の可能性を高めるかどうかについて関心が高かった。

Rosenthal (1966) は，期待者の被期待者の行動に対す る期待を,予言の自己成就 (self-fulfilling prophecy) の 文脈で説明し，教師の期待は子どもの知的成長に影響を 及ぼすことを見出した。それ以後，期待一行動に関する 研究は, 学業活動 (Beez, 1968; Meichenbaum, Bower, \& Ross, 1969), 教師一生徒相互作用 (Rist, 1970; Sutherland \& Goldschmid, 1974), 学級学習活動の適 切性 (Meichenbaum et al. 1969) および読書 (Pallardy, 1969）等にその篥囲を広げて行なわれたが，期待者の期 待と被期待者のパフォーマンス間にポジティブな関係が
あることが報告されてきた。

こてで，てのように，認知特性と動機づけ特性とをあ わせもち，行動の選択，煥起，維持を可能にする情動 (木村, 1978) である期待 (expectancy) によって起こ る被期待者の行動・知覚変容のメカニズムの究明は必要 であると考えられる。

Baumeister, Cooper \& Skib (1979) は，自己概念の 維持と認知的均衡という内的目標より, ある状況で他者 に自分の特別な印象を伝達しようとする欲求，すなわち， 伝達的あるいは自己呈示的関心が，個人の期待一反応の 関係において重要な決定因となるかも知れないと主張し ている。彼らは, 期待に対する被期待者の反応は, 被期 待者のその期待行動に対する評価と, 人から㷌属される 自分の特性についての知覚によって決定されると述べて いる。従って, 特性と行動の間に関係がない場合であっ ても, observer は行動を特性に関連させて解釈するだ ろうということを, 被期待者は認めなければならないと 主張している。

しかし, Archibald (1974) と Murphy (1974) は, いくつかの内的一認知的ダイナうックスを提起して, 期 待が被期待者の目標と動因に及ぼす影整を説明している。

また, Jones \& Panitch (1971) は, 期待者の期待に よる被期待者の行動を, Merton の予言の自己成就の定 義を実現させる相互作用の結果として規定している。

従って, 変容した被期待者の行動が期待者の期待に内 在する定義と一致することとして, observer によって 判断することが予言の自己成就の概念の前提条件である (Darley et al., 1980) と考えられる。

さて, このような期待一行動の次の段階, すなわち, 実際に起てった自分の行動の変容についての被期待者の 解釈段階で，対人知覚にいかなる変容が起てるかに関す る研究はあまりなされててなかった。被期待者の行動は 期待者の期待によって変容し，この変容した行動につい

1) 本研究に対して御指導と御援助を頂いた九州大学狩野素朗教授と原田純治助手に感謝の意を表します。 
ての被期待者の解釈は, 被期待者の自己概念とその後の 行動をポジティブな方向に導くと考えられる。

Darley et al. (1980) は, 乙の段栺で, 被期待者は変 容した自分の行動から自分自身についての新しいものを 推論することによって，それまでの自己概念を変えるか も知れないと述べている。言いかえれば，反応について の自己帰属は, 被期待者に, “自分はそういう場合はそ ういうふうに行動する人間である”と知覚させるかも知 れない。彼らは, この自己像の変容の過程を具体的に次 のように説明している。すなわち, 自己帰属は被期待者 に状況 (situation)，期待者 (perceiver) に対する新し い態度を形成させ，自分自身 (himself or herself) につ いてそれまで見つけなかった新しいものを見つけさせる。 その結果, 被期待者は以前の態度を分極化し，自己像のあ る側面を変えるてとになる。そして，ある状況において の行動から推論された自己帰属は，新しい状況において の行動にも影響を及ぼすととが見出されている（Comer \& Laird, 1975)。

梶田（1980）は，人は他者からの徵きかけを，自らの 自己評価のレベルを投影するような仕方で認知すると言 っている。てれは，他者からの期待を自分の自己概念と 関連づけて解釈するととを意味すると考えられる。

ここで，てのように，他者の期待によって起因した自 己概念の変容は，その他者についての被期待者の知覚の 変容も伴うであろうと考えられる。

Darley et al. (1980) は, 被期待者の変容した自分の 行動についての推論は, 期待者への新しい態度を形成さ せ, 期待者についてのその後の知覚・行動に影響を及ほ すと述べている。

以上の諸行究の知見から，行動の規定因としての期待 は，被期待者の行動をポジィブな方向への変容に導く 可能性を持っていることが示唆される。また, ての㚆容 した行動について被期待者の知覚は, それまでの自己像, およびそういうような行動の変容をもたらした期待者に ついての知覚に影響を及ぼすと考えられる。

本研究は, 他者が自己に対してポジティブな期待を持 っているとき，その期待に起因して変容した自己行動に ついての知覚は, 自己概念をどのように変容させるか, また，それに伴って，期待を待っている他者についての 知覚をどのように変えるのかを検討する。

以上の議論から次の仮説を設定する。

仮説 1 被期待者の行動の変容は, 期待操作のない条 件より期待操作がある条件でより大きいであろう。

仮説 2 被期待者の自己概念と期待者についての知覚 の変容は, 行動の変容の大きい群が行動の変容の小さい
群より大きいであろう。

$$
\text { 方法 }
$$

被験者 中学 2 年生, 男女計 94 名, 乙のうちセッショ ン 2 に参加しなかった 2 名とセッション 1 での課題得点 があまり高いので，期待操作ができない 4 名が除外され， 結局88名が対象となった。

作業課題 被験者にとってはあまり意味のない単調で 退届な課題として, 逆単純加算課題を用いた。用紙には 1 行に 1 桁 ( 1 から 8 まで) の数字が 51 字で 33 行, 計 1683字が印刷されており，各数字の下に 1 数字が書ける スペースがある。“最初は 1 番右の段の下から上へ，そ して， 2 番めの右の段の下から上へと，各数字に 1 を加 えた数字をできるだけ速く，そして，正確に「やめ」の 合図があるまで書いて下さい”という教示のもとに, 15 分間, 逆単純加算作業をさせた。

対人評価尺度 上田・谷口（1975）に従い，社会的に 望ましい人格を表わす修飾語とその反意語からなる15段 階評定尺度を用いた。20対の中から予備調查の結果によ って選ばれた12対で構成された。具体的には，意欲的な 一無気力な, 責任感のある一無責任な, 陽気な一陰気な, 誠実な一不誠実な，勇敢な一臆病な，積極的な一消極的 な, 社交的な一非社交的な, 思いゃりのある一思いやり のない, 親切な一不親切な, 勤勉な一急慢な, 元気な一 元気のない, 清潔な一不絜な, の12刘である。

実験計画 2 (教師からの期待の有・無) $\times 2$ (パフォ ーマンス差) $\times 2$ (評定対象) の 3 要因計画である。

実験は 1 週間の間隔をおいて 2 セッションに分けて行 なわれた。被験者は期待条件（期待操作が行なわれた条 件）と統制条件（期待操作が行なわれなかった条件）に 半分ずつ無作為に割当てられた。両条件別に，セッショ ン 1 とッション 2 間の課題遂行得点の差の中央值によ って大差群と小差群に分けられた。前者の課題遂行得点 の差の平均値は $148.91(S D=32.61)$, 後者の課題遂行 得点の差の平均值は $69.02(S D=40.13)$ であり, 両群 の平均值に有意差が見出された $(t=10.13, d f=86$, $p<$.001)。

手続き〔セッション 1〕まず,「本調査は, 中学校の 生徒と教師の種々の性格特性を究明しょうとする研究で ある」旨の教示がなされた。被験者の疑いを減じるため に, いくつかの英語教授方法に関する正あるいは負の意 見を評定させた。その次に, 被験者は, 自己と教師につ いての評定と課題遂行が求められた。

〔セッション2]被験者は, 信用できる評定を得るた めに, 一定期間後もう一度課題と評定を行なう必要があ 
るという説明を受けた。期待条件の被験者はセッション 1 での本人の課題遂行得点と能力等級 ( $\mathrm{A}, \mathrm{B}, \mathrm{C}, \mathrm{D}$ 級) が莗かれている「通知票」をもらった。また, 能力等級 別の B校生の平均得点と本校生のセッション 1 での平均 得点およびセッション 2 での予想平均得点（本校の 5 人 の数学教師が $B$ 校生の得点と本校生のセッション 1 の得 点から算定した期待点数）が対比された表がスライドで 期待条件群の被験者に提示された。予想平均得点は, セ ッション 1 での本校の各等級の平均点数より 120 点 350 点高い点数であり, $\mathrm{B}$ 校の各等級の平均点より 87 点〜 476 点高い点数であった。この対比表を通じて, 被験者は $\mathrm{B}$ 校の被験者の得点とセッション1での自分の得点および 教師からの期待点数を比較するてとができる機会を得た。 統制条件群にはいかなる対比表の提示もなかった。その 次に,もう一度セッション 1 での課題を 15 分間させ, そ の得点を通知票に書き込ませ, セッション 1 とセッショ ン 2 間の得点の差も計算させ, 通知票を回収した。次い で, 被験者たちが, いくつかの英語の教授方法について ポシティブあるいはネガティブな意見を発表している間, 実験者はセッション間の課題遂行得点の差の中央値によ って被験者を大差群（以下 HDP 群と略す）と小差群 （以下 LDP 群と略す）に分けた。実験者はその結果を 書き込んだ通知票を再び被験者に配付し，セッション間 の課題遂行得点の差を被験者全体の水準加ら見るとき， 自分は大差群に属するか，小差群に属するかを確かめる よう求めた。最後に，セッション1での評定のコピーを 配付し，もう一度自己と教師についての評定を被験者に 求めた。記入終了後, 本研究の本当の目的について説明 し，実験を終了した。

従属変数の測定 対人評価尺度の 12 対の両極形容詞尺 度を用い，15点尺度上に「自己」「教師」についてのパ ーソナリティ認知評定を求めた。各項目でポジティブ15 点〜ネガティブ1点とし, 合計得点を算出した。セッシ ョン 2 の得点からセッション 1 の得点を差し引いてセッ ション間の自己評定と教師評定の差が求められた。

\section{結果}

初期知喾の同質性の検討 期待条件群と統制条件群の 同質性を検討するために，セッション 1 での対人評価尺 度の評定得点について 2 (期待, 統制条件) $\times 2$ (自己, 教師）の 2 要因の分散分析を行なった結果, 条件群の要 因にも，評定対象の要因にも有意差は認められなかった $(F(1,86)=1.89$, n.s. と $F(1,86)=1.22$, n.s. $)$ 。

操作チェック他者加らの期待が, 自分の “逆単純加 算作業”に及ほした影響を，1 (全く関係がない)〜 7 (非
常に関係がある）の 7 点尺度上で評定させた結果，期待 条件 $(\bar{x}=5.96)$ と統制条件 $(\bar{x}=1.21)$ との間に有意な 差が認められた $(F(1,84)=6.98, p<.01)$ 。また, 自 分の “行動の変化” は, 他者の “期待”によってどの程 度影響を受けていると思うかを 7 点尺度上で評定させた。 教師からの期待の有・無とパフォーマンス差の交互作用 に有意な傾向が見られた $(F(1,84)=3.91 ， p<.10)$ 。 以上より, 期待の操作は有効であったと言える。

期待効果と行動, 知觉の変容 期待条件と統制条件別 に, HDP 群と LDP 群のセッション1とセッション2 における対人評価尺度の評定得点の平均值を図示したも のが Fig. 1 と Fig. 2 である。セッション間の評定得 点差について 2 (期待, 統制条件) $\times 2$ (HDP, LDP 群) $\times 2$ (自己, 教師) の 3 要因の分散分析を行なった結 果, 教師汃らの期待の有・無の主効果 $(F(1,84)=5.02$, $p<.05)$ とパフォーマンス差の主効果 $(F(1,84)=4.31$, $p<.05)$ が有意であった。また，教師からの期待の有 ・無とパフォーマンス差の交互作用 $(F(1,84)=4.08$,

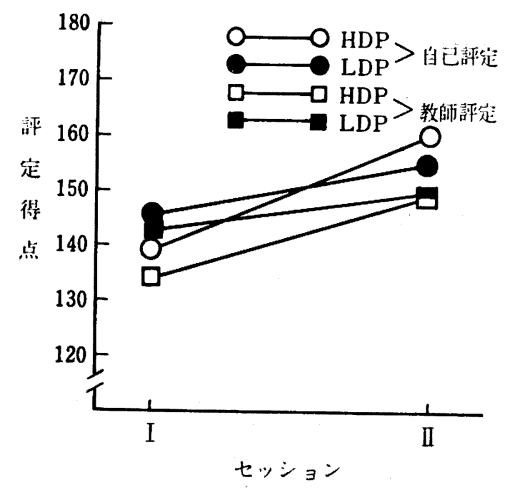

Fig. 1. 期待条件での HDP 群と LDP 群の評定得点の平均値

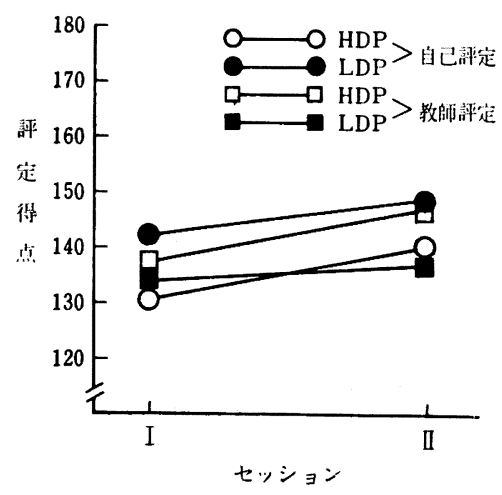

Eig. 2. 統制条件での HDP 群と LDP 群の評定得点の平均値 
$p<.05)$ が有意であった。この交互作用につき，単純効 果の検定を行なった結果，HDP 群において期待条件と 統制条件の間に有意差 $(F(1,84)=6.97, p<.01)$ がみ られ，また，期待条件において HDP 群と LDP 群の間 にも有意差 $(F(1,84)=4.33, p<.05)$ がみられた。す なわち, 対人評価尺度のセッション間の評定得点の変容 は, 期待条件において LDP 群より HDP 群がより大き かったが，HDP 群においては統制条件よりも期待条件 で変容がより大きいととが見出された。

Table 1 は, 期待条件と統制条件での, HDP 群と LDP 群の自己評定と教師評定の相関を示している。相関の有 意差検定の結果，4つの相関係数の間に有意な差がみら れなかった。すなわち，相関係数間の同質性がみとめら れ，期待が高いほど自己評定の相関は高くなるという結 果が得られた。

Table 条件別の自己評定と数師砰定の相関

\begin{tabular}{|c|c|c|c|c|}
\hline \multirow{2}{*}{ 相䦛傎 } & \multicolumn{2}{|c|}{ 期待条件 } & \multicolumn{2}{|c|}{ 統制条件 } \\
\hline & HDP & $\overline{L D P}$ & HD P & $\overline{\text { LDP }}$ \\
\hline \multirow[t]{2}{*}{$r$} & .65 & 47 & .35 & .16 \\
\hline & & $x^{2}=3$ & $.30)$ & \\
\hline
\end{tabular}

対人評価尺度の下位項目の評定の変容 Table 2 は, 期待条件と統制条件ごとの対人評価尺度の下位項目のセ
ッション間の評定得点差の 平均值と, 各項目ごとに 2 (期待, 統制条件) $\times 2$ (HDP, LDP 群) $\times 2$ (自己, 教 師）の 3 要因の分散分析を行なった結果, 有意な主効果 あるいは交互作用が見出された項目を示したものである。

まず，「意欲性」と「責任性」については, パフォー マンス差の主効果のみに有意差がみられた。

「誠実性」については，教師からの期待の有・無の主 効果とパフォーマンス差の主効果, および教師からの期 待の有無と評定対象の交互作用に有意差が見られた。単 純効果の検定をしてみると，期待条件において自己と教 師の間に有意差 $(F(1,168)=4.22, p<.05)$ がみられ, また自己における期待条件と統制条件の間にも有意差 $(F(1,168)=5.19, p<.05)$ が見られた。すなわち，自 己について統制条件より期待条件で評定得点の変容が大 きかったが，期待条件においては教師よりも自己につい ての評点得点の変容が大きいととが見出された。

「積極性」については, 教師からの期待の有・無の主 効果, 教師からの期待の有・無とパフォーマンス差の交 互作用および教師からの期待の有 - 無と評定対象の交互 作用に有意差がみられた。まず, 教師からの期待の有・無 とパフォーマンス差の交互作用について単純効果の検定 を行なった結果, 期待条件において, HDP 群と LDP 群 の間に有意差 $(F(1,84)=6.95, p<.01)$ がみられ, ま た HDP 群において期待条件と統制条件の間にも有意差 $(F(1,84)=4.44, p<.05)$ がみられた。すなわち, HDP

Table 2

対人評価尺度の下位項目の評定得点差の平均值と分散分析表

\begin{tabular}{|c|c|c|c|c|c|c|c|c|c|c|c|c|c|c|c|}
\hline & \multicolumn{4}{|c|}{ 期 待条 件 } & \multicolumn{4}{|c|}{ 統制条件 } & \multicolumn{7}{|c|}{$F$ 値 ( 1 以上のもの) } \\
\hline & \multicolumn{2}{|c|}{$\begin{array}{l}\text { HDP群 } \\
(N=22)\end{array}$} & \multicolumn{2}{|c|}{$\begin{array}{c}\text { L D P 群 } \\
(N=22)\end{array}$} & \multicolumn{2}{|c|}{$\begin{array}{l}\text { H D P 群 } \\
(N=22)\end{array}$} & \multicolumn{2}{|c|}{$\begin{array}{c}\text { L D P 群 } \\
(N=22)\end{array}$} & \multirow{2}{*}{\multicolumn{2}{|c|}{ 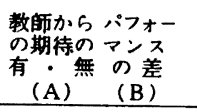 }} & \multirow[t]{2}{*}{$A \times B$} & \multirow{2}{*}{$\begin{array}{l}\text { 鼓 定 } \\
\text { 対 象 } \\
\text { (C) } \\
\end{array}$} & \multirow[t]{2}{*}{$A \times C$} & \multirow[t]{2}{*}{$\mathrm{B} \times \mathrm{C}$} & \multirow{2}{*}{$\begin{array}{l}A \times B \\
\times C\end{array}$} \\
\hline & 自己 & 教的 & 自己 & 教 師 & 自己 & 教 師 & 自己 & 数師 & & & & & & & \\
\hline \multirow[t]{2}{*}{ 意欲性 } & 2.22 & 2.00 & 1.10 & 0.92 & 1.48 & 0.94 & 0.51 & 1.21 & & & & & & & \\
\hline & $(0.71)$ & $(0.83)$ & $(0.69)$ & $(0.71)$ & $(0.73)$ & $(0.47)$ & $(0.58)$ & $(1.51)$ & 3.213 & $5.261^{*}$ & 1. 334 & & & 1.132 & \\
\hline \multirow[t]{2}{*}{ 青任性 } & 1.83 & 2.71 & 0.93 & 1.03 & 1.26 & 1.81 & 0.66 & 0.74 & & & & & & & \\
\hline & $(0.87)$ & $(0.77)$ & $(0.41)$ & $(0.68)$ & $(0.71)$ & (1. 33) & $(0.31)$ & $(0.49)$ & 1.936 & 4. $773^{*}$ & & & 1.007 & & 1.128 \\
\hline \multirow[t]{2}{*}{ 誠実性 } & 3. 36 & 2.11 & 2. 39 & 0.54 & 1.13 & 1. 19 & 0.51 & 0.68 & & & & & & & \\
\hline & $(0.99)$ & $(0.74)$ & $(0.73)$ & $(0.59)$ & $(0.44)$ & $(0.58)$ & $(0.70)$ & $(0.63)$ & $6.134^{*}$ & 4. $196^{*}$ & 1.177 & 2.112 & $7.323^{* *}$ & 1.417 & 1. 772 \\
\hline \multirow[t]{2}{*}{ 樌極性 } & 2.69 & 2.43 & 2.01 & 1. 89 & 1.14 & 0.96 & 0.70 & 0.71 & & & & & & & \\
\hline & $(0.96)$ & $(0.83)$ & $(0.39)$ & $(0.61)$ & $(0.57)$ & $(0.26)$ & $(0.51)$ & $(0.33)$ & $7.334^{* *}$ & 4. 016 & $6.827^{*}$ & & 5. $036^{*}$ & & 1.968 \\
\hline \multirow[t]{2}{*}{ 社交性 } & 1. 82 & 0.86 & 0.94 & 1.01 & 1.26 & 0.77 & 1.76 & 0.61 & & & & & & & \\
\hline & $(0.86)$ & $(0.31)$ & $(0.57)$ & $(0.72)$ & $(1.01)$ & $(0.41)$ & $(0.48)$ & $(0.43)$ & 3. 907 & 2. 396 & 2. 989 & 4. $132^{*}$ & & 1. 232 & \\
\hline \multirow[t]{2}{*}{ 勤勉さ } & 2. 88 & 2. 79 & 1.24 & 0.99 & 1.04 & 0.61 & 0.52 & 0.51 & & & & & & & \\
\hline & $(0.54)$ & (1.51) & $(0.49)$ & $(0.61)$ & $(0.65)$ & $(0.37)$ & (1.34) & $(0.39)$ & $5.116^{*}$ & 4. $372^{*}$ & 2.023 & 1.295 & 1.064 & 1.690 & 2.071 \\
\hline 元気さ & $\begin{array}{c}3.01 \\
(0.42)\end{array}$ & $\begin{array}{c}1.04 \\
(0.53)\end{array}$ & $\begin{array}{c}1.67 \\
(0.31)\end{array}$ & $\begin{array}{c}1.88 \\
(1.11)\end{array}$ & $\begin{array}{c}1.01 \\
(0.68)\end{array}$ & 1. 17 & 0.61 & 0.43 & & & & & & & \\
\hline & & & & & & $(0.51)$ & $(0.59)$ & $(0.47)$ & 2. 090 & 7. $321^{* *}$ & $6.394^{*}$ & 1.012 & 0.474 & & \\
\hline
\end{tabular}




\section{崔 : 社会的相互作用過程における期待が対人知覚の変容に及ほすす効果}

群においては統制条件より期待条件で評定得点の変容か： より大きかったが，期待条件においては，LDP 群より HDP 群の変容が大きいととが見出された。次に, 教師 からの期待の有・無と評定対象の交互作用について単純 効果の検定を行なった結果, 期待条件において自己と教 師の間に有意差 $(F(1,168)=4.01, p<.05)$ がみられ, また教師において期待条件と 統制条件の間にも有意差 $(F(1,168)=4.46, p<.05)$ が見られた。すなわち，教 師において統制条件より期待条件で得点の変容がより大 きかったが，期待条件においては自己よりも教師につい ての評定で得点の変容が大きいととが見出された。

「社交性」については，評定対象の主効果のみに有意 差が見られた。

「勤勉さ」については，教師からの期待の有・無の主 効果とパフォーマンス差の主効果に有意差が見られた。

「元気さ」については，「パフォーマンス差」の主効 果および教師からの期待の有・無とパフォーマン差の交 互作用に有意差が見られた。単純効果検定の結果, HDP 群と LDP 群において期待条件と統制条件の間に有意差 (それぞれ， $F(1,84)=4.03, \quad p<.01$ と $F(1,84)=$ 4. 94，p<.05）がみられ，また期待条件において HDP 群と LDP 群間に有意差 $(F(1,84)=5.46, \quad p<.01)$ が見られた。すなわち, HDP 群と LDP 群において, 統制条件より期待条件で評点得点の変容が大きいととが 見出された。また，期待条件においては，HDP 群で LDP 群より評点得点の変容か大きいととが見出された。

\section{考察}

まず，期待者の期待が被期待者の行動に及ほす影響に ついて考察しよう。セッション間の期待条件群の課題遂 行得点の差 $(\bar{x}=12.76)$ は, 統制条件群の課題遂行得点 の差（ $\bar{x}=6.53 ）$ より大きかった。とれは，期待者の期 待と被期待者のパフォーマンスの間にはポジティブな関 係があり (Crano et al. , 1978)，また，期待効果は両者間 の相互作用の質を強化する (Meichenbaum et al., 1969) という諸知見と一致するものであった。 Sutherland （1974）が主張するように, 被期待者の水準についての喼 知的ズレが期待者と被期待者の間で大きい場合, 期待効 果が起こり，それが被期待者の行動変化の要因になると 言えよう。Snyder \& Swann (1978) と Darley et al. (1980) は, 乙のような期待一行動の関係を,より具体的 に次のように説明している。すなわち，被期待者が自分 自身を，期待者が期待した正にその特質に帰属する過 程には予言の自己成就が作用し，異なる他者あるいは異 なる状況の相互作用においても，乙の自己帰属（selfascription） が被期待者に期待者の最初の期待に一致す るよう行動させると主張している。予言の自己成就と自 己帰属のメカニズムが被期待者のポジティブな行動変容 の要因となると考えられる。

しかし, 本研究は, 期待者の期待と被期待者のパフォ ーマンス変容間の関係より, 対人知覚に及ほす社会一行 動的期待の潜在的影響の結果に関心があった。換言すれ ば，他者の期待によって変容した自分の行動に対する解 釈は, 自分の自己概念とその後の他者についての知覚を 変容させるであろうと考えた。

本研究の結果は，セッション間の評定対象についての 評定の変容において, 期待者の期待と被期待者のパフォ ーマンス間の交互作用が有意であるととを示したが，評 定対象間ては有意でなかった。との結果から, 期待者の 被期待者に対する好意的期待は，被期待者のポシシィブ な自己概念を形成させ，自己概念が強化されれば，被期 待者の新しい反応形成を期待するてとができるオペラン 卜条件づけによる解秎も可能であると考えられる。

上述したように，ある状況の行動から推論されたポジ テイブな自己帰属は，新しい状況での行動と認知過程に ポシティブな影響を及ぼすかも知れない。しかし，期 待者の最初の期待に misperception が含まれると, Merton が指摘しているように，相互作用は “過誤の支 配” (reign of error) の結果となるかも知れない。期待 条件の評定の対象においては有意差が見られなかったが， セッション間の自己評定の変容の差 $(\bar{x}=17.71)$ と教師 評定の変容の差 $(\bar{x}=15.95)$ の程度が類似であることは, 被験者が自己評定ばかりでなく他者評定もポジィブな 方向に変容させたととを示すものである。このととは, 被期待者の変容した自分の行動についての知覚は, 期待 者についての被期待者のその後の知覚にも影響を及ぼす という Darley et al. (1980) の主張を支持するもので あった。

次に, 対人評価尺度項目の結果について考察してみよ う。「意欲性」と「責任性」についてはパフォーマンス 差の主効果がみられ，教師からの期待の有・無の主効果 はみられなかった。「積極性」と「勤勉さ」については 教師からの期待の有 ・ 無の主効果, 教師からの期待の有 ・無とパフォーマンス差の交互作用に有意差がみられた。 「元気さ」についてはパフォーマンス差の主効果および 教師からの期待の有・無とパフォーマンス差の交互作用 が有意であった。期待者と被期待者の社会的相互作用過 程で，てれらの社会的相互作用を表わすパーソナリティ 特性語と被期待者のパフォーマンス間に関係があるとい 
うことは, 社会一行動的期待の潜在的機能が知覚・行動 変容の強い規定因として働いているてとを物語っている。 換言すれば，乙れらの結果は，ポシティブな自己像と関 俰がある正直性, 誠実性, 信頼性等の次元は, 内集団行 動における規範的期待にも関わるという Brewer (1979) の主張を支持するものであった。

今後の研究では, 期待者一被期待者の相互作用によっ て起因した自己概念の変容は, 被期待者の内部特質とど のような関係を持っているか, また, 自己知覚の変容は private-self evaluation の維持のためか public-self evaluation の操作のためかを究明する必要があろう。

\section{要 約}

本研究は, 他者の期待によって起こった自己行動の変 容を知覚した被期待者は, 自己概念およびそのような期 待を持つ他者についての知覚をどのように変容させるか を解明することによって, 社会的相互作用過程で期待效 果が対人知覚の変容に及ぼす影響を検討した。

期待条件と統制条件に割当てられた被験者たちは，セ ッション 1 とセッション 2 間の課題遂行得点の差の中央 值によって各々 2 群（大差群，小差群）に分けられ，対 人評価尺度で自己と教師を評定した。セッション間の自 己と教師についての評定の差が求められた。

主な結果は次の通りであった。

（1）期待操作が行なわれた条件（期待条件）の被験 者の方が，期待操作が行なわれなかった条件（統制条件） の被験者の方より評定対象についての評定得点の変化が セッション間で大きかった。

（2）セッション間の課題遂行得点差の大きい群が， 小さい群よりも対人評価尺度の評定得点差も大きかった。 また, 教師からの期待の有・無とパフォーマンス差の交 互作用も有意であった。すなわち，期待によって起てっ た自己行動の変容は, 対人知覚の変容にも影㔖を及ほす ことが見出された。

（3）対人知覚尺度の下位項目についての分散分析の 結果から，社会的相互作用を表わすパーソナリティ特性 語（意欲性，責任性，勤勉さ，元気さ）と被期待者のパ フォーマンスの間に関係があることが明らかになった。

ある状況の行動から推論されたポジティブな自己帰属 は，新しい状況での行動と認知過程にポジティブな影魄 を及ぼす考察された。

\section{引用 文 献}

Archibald, W.P. 1974 Alternative explanations for self-fulfilling prophecy. Psychological Bulletin, 81, 74-84.
Baumeister, R. F., Cooper, J. \& Skib, B. A. 1979 Inferior performance as a selective response to expectancy: Taking a dive to make a point. Journal of Personality and Social Psychology, 37, 424-432.

Beez, W. V. 1968 Influence of biased psychological reports on teacher behavior and pupil performance. Proceedings of the 76 th Annual Convention of the American Psychological Association, 3, 605-606.

Brewer, M. B. 1979 In-group bias in the minimal intergroup situation: A Cognitive-motivational analysis. Psychological Bulletin, 86, 307-324.

Comer, R. \& Laird, J. D. 1975 Choosing to suffer as a consequence of expecting to suffer: Why do people do it? Journal of Personality and Social Psychology, 32, 92-101.

Crano, W. D. \& Mellon, P. M. 1978 Casual influence of teacher's expectations on children's academic performance: A cross-lagged panel analysis. Journal of Educational Psychology, 70, 39-49.

Darley, J. M. \& Fazio, R. H. 1980 Expectancy confirmation processes arising in the social interaction Sequence. American Psychologist, 35, 867-881.

Jones, S. C. \& Panitch, D. 1971 The self-fulfilling prophecy and interpersonal attraction. Journal of Experimental Social Psychology, 7, 356-366.

梶田教一 1980 自己意識の心理学. 東京大学出版会. 木村 易 1978 期待. 心理学小辞典 有斐閣双書.

Meichenbaum, D. H. , Bowers, K. S. \& Ross, R. R. 1969 A behavioral analysis of teacher expectancy effect. Journal of Personality and Social Psychology, 13, 306-316.

Merton, R.K. 1957 Social theory and social structure. New York: Free Press of Glencoe.

Murphy, J. 1974 Teacher expectations and the working class under-achievement. The British Journal of Sociology, 25, 326-344.

Pallardy, N. P. 1969 What teachers believe, what children achieve. Elementary School Journal, 69, 370-374.

Rist, R. C. 1970 Student social class and teacher expectations: The self-fulfilling prophecy in ghetto education. Harvard Educational Review, 40, 411-451.

Rosenthal, R. 1966 Experimenter effects in behavioral research. New York: Appleton-Century-Crofts.

Snyder, M. L. \& Swann, W. B. 1978 Behavioral Confirmation in social interaction: From social perception to social reality. Journal 
of Experimental Social Psychology, 14, 148162.

Sutherland, A. \& Goldschmid, L. M. 1974 Negative teacher expectation and IQ change in children with superior intellectual potential. Child Development, 45, 852-856.

-1984 年 7 月 7 日 受稿, 1984 年 8 月 13 日 受理一

\title{
INFLUENCES OF EXPECTANCY EFFECT ON INTERPERSONAL PERCEPTION IN SOCIAL INTERACTION PROCESS
}

\author{
CHOI, KWANG SUN \\ Kyushu University
}

\section{ABSTRACT}

The present study was designed to exeamine how the target's interpretation of his behavior being modified by the perceiver's expectancy leads to changes in the self-concept and cognition toward the perceiver.

The study was conducted in two sessions held one week apart. Subjects were 88 middle school students. They were randomly assigned to the following two conditions: (1) Expectancy condition; expectancy manipulation was conducted, (2) Control condition; no expectancy manipulation was conducted. Subjects in each condition were divided into two groups according to the median algebraic difference between the task performance scores of session 1 and those of session 2 . Bet-
\end{abstract}

ween the first and second sessions, subject's ratings of self and teacher were measured.

Major results were as follows:

(1) Between the first and second sessions, changes in ratings of self and teacher were larger under expectancy conditions than under control conditions.

(2) The group showing the large behavior changes between the first and second sessions changed ratings of self and teacher more than the group showing the small behavior changes did.

(3) Such traits as trustworthiness, responsibility, loyalty, and diligence were related to changes in a student's self-concept which resulted from his behavior being modified by teacher's expectancy.

Key words: expectancy effect, self-fulfilling prophecy, self-concept, performance, perception, social interaction sequence. 